\title{
トピックス
}

\section{II. 脳卒中}

\section{2. 脳卒中急性期医療の地域連携とtele- medicine}

\section{井口 保之 三村 秀毅 小松 鉄平}

要旨

急性期脳卒中診療は経静脈的線溶療法が認可されて以降, 劇的に変化している. 一人でも多くの脳卒中 患者を救うためには，市民，医療機関および行政が協力し，1）公開講座，広告，マスメデイアを用いた継 続的な脳卒中啓発活動，2)救急隊は標準化された病院前脳卒中スケールを運用し脳卒中疑い傷病者を収容 し，脳卒中対応施設に搬送，3）遠隔診療支援システムを積極的に運用し脳卒中対応施設は患者受け入れ体 制を整備することが重要である.

〔日内会誌 $103 ： 1783 \sim 1790,2014$ 〕

Key words 経静脈的線溶療法, 市民啓発, 脳卒中病院前救護, telemedicine

はじめに

国民病である脳卒中を征圧するには，脳卒中 発症予防と発症時の早期治療が重要である。脳 卒中の $2 / 3$ を占める脳梗塞に対し, 早期治療の 切り札である組織プラスミノーゲンアクティベー ターを用いた経静脈的血栓溶解療法（t-PA静注 療法）が実施可能となったが, t-PA静注療法は 脳卒中専門施設 (1 次脳卒中センターもしくは統 括脳卒中センター）に搬送された急性期脳梗塞 例の $5 \%$, 超急性期脳梗塞例の $16 \%$ に実施され ているに過ぎない ${ }^{1)}$. 一人でも多くの市民を救う ためには, 超急性期脳梗塞（疑い）患者を発症 後可及的速やかに脳卒中専門施設へ搬送し遅滞
なく診療を行う必要がある. 2012 年夏より, tPA静注療法実施確認項目である発症から治療開 始までの時間（onset-to-needle time：ONT）は 3 時間から 4.5 時間に延長されたが,この改訂は 悠長に治療できることを意味しているのではな い. ONTが短ければ転帰は良好となることは自 明であり,「ONTを 4.5 時間以内に」,「来院から 治療開始までの時間 (door-to-needle time：DNT) を 1 時間以内に」短縮する取り組みを経て,「発 症から 1 時間以内（golden hour）に治療を開始 する」ことを目指す時代を迎えている2). 本稿で は, 早期治療開始に必要な(1)市民に対する脳卒 中啓発活動, (2)脳卒中病院前救護 (prehospital stroke life support: PSLS), (3)telemedicineを含 む遠隔診療支援について概説したい.

東京慈恵会医科大学神経内科

Neurological Common Diseases in the Super-Elder Society. Topics : II. Stroke ; 2 . Prehospital acute stroke management. Yasuyuki Iguchi, Hideki Mitsumura and Teppei Komatsu : Department of Neurology, Jikei University School of Medicine, Japan. 


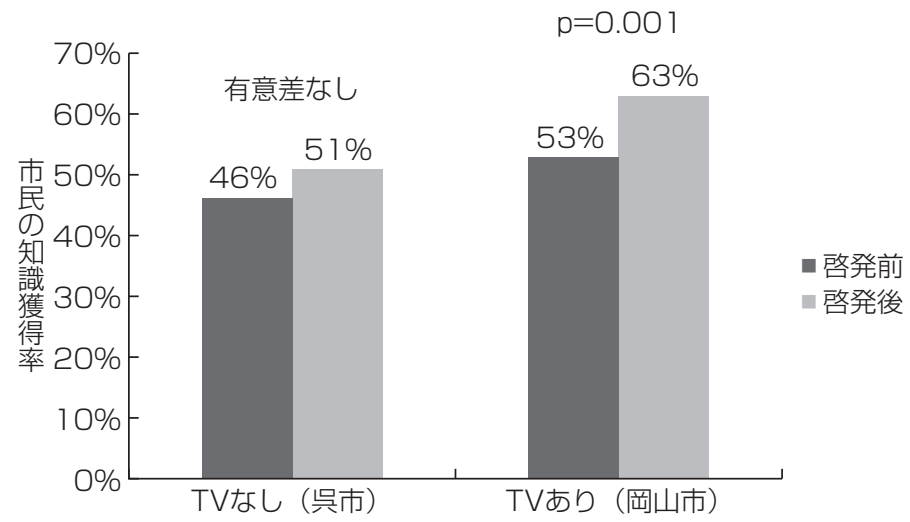

図 1

吳市は通常の媒体（パンフレット, チラシ, ポスター, 市民公開講座） による脳卒中啓発活動を, 岡山市は通常の媒体に加えてテレビプロ グラムによる啓発活動を実施した. 1 年間の啓発活動実施前後で, 市民の知識獲得率を比較すると, 岡山市では知識獲得率が上昇した.

\section{1. 市民に対する脳卒中啓発活動}

市民が脳卒中を発症した時に,「市民が脳卒中 と気が付き」3),「直ちに救急隊を呼ぶ」等の適切 な行動を起こすことに主眼をおいた脳卒中啓発 活動は全国で展開されている，啓発活動の媒体 は, ポスター, 新聞・雑誌における広告, 市民 公開講座，ラジオ・テレビなどによる広報プロ グラムである.テレビを用いた啓発活動を重点 的に行った岡山市と通常の啓発活動のみを実施 した呉市を比較し, 啓発期間の前後で各地域市 民の知識習得率を比較した。テレビを用いた岡 山市では, 呉市と比較し市民の知識獲得率は啓 発後に上昇しており，テレビを用いた脳卒中啓 発活動は効果が高いことを示した（図 1)。米国 では一般市民を対象とし(1)顔面麻痺(2)上肢麻痺 (3)言語障害の 3 項目に(4)発症時間を加えた ACT FAST (Face, Arms, Speech, and Time) キャン ペーンを展開し, ポスターおよびテレビプログ ラムを用いた脳卒中啓発活動が進められている. 我が国でも, 大阪府, 福岡県, 神奈川県等で地 域医療システムの実情に即したキャンペーンが
展開されている.

注目すべき取り組みは小中学生に対する脳卒 中啓発活動である。期待される効果は，1)若年 からの生活習慣を改善し対象となる小中学生自 体の脳卒中発症予防効果が期待できる，2) 親近 者が脳卒中を発症した場合に発見者として適切 な行動がとれる，さらに3）親近者に対して自身 が得た脳卒中啓発知識を広める等である。本邦 では横田らが中心となり小中学生に対する脸卒 中啓発活動を展開し日本版ACT FASTキャン ペーンの効果を検証している.

脳卒中の啓発効果向上に関連する因子は, 女 性, 高学歴, 高収入, 発症時に同居者もしくは 発見者の存在, 突然発症, 重篤な神経症状など である。これら因子を勘案し各種媒体を用いて 繰り返し重点的に脳卒中啓発活動を実施するこ とで市民の関心と知識は高まる。一方で啓発活 動の中断によって市民の関心と知識は低下する. 脳卒中啓発活動の課題は, 1) 啓発活動の継続的 実施にかかる人的・経済的負担を解決すること， 2) 脳卒中啓発活動の結果, t-PA静注療法実施率 が向上し, 社会復帰可能となる市民が増加する 等を科学的に検証し,より良い啓発活動を開発・ 


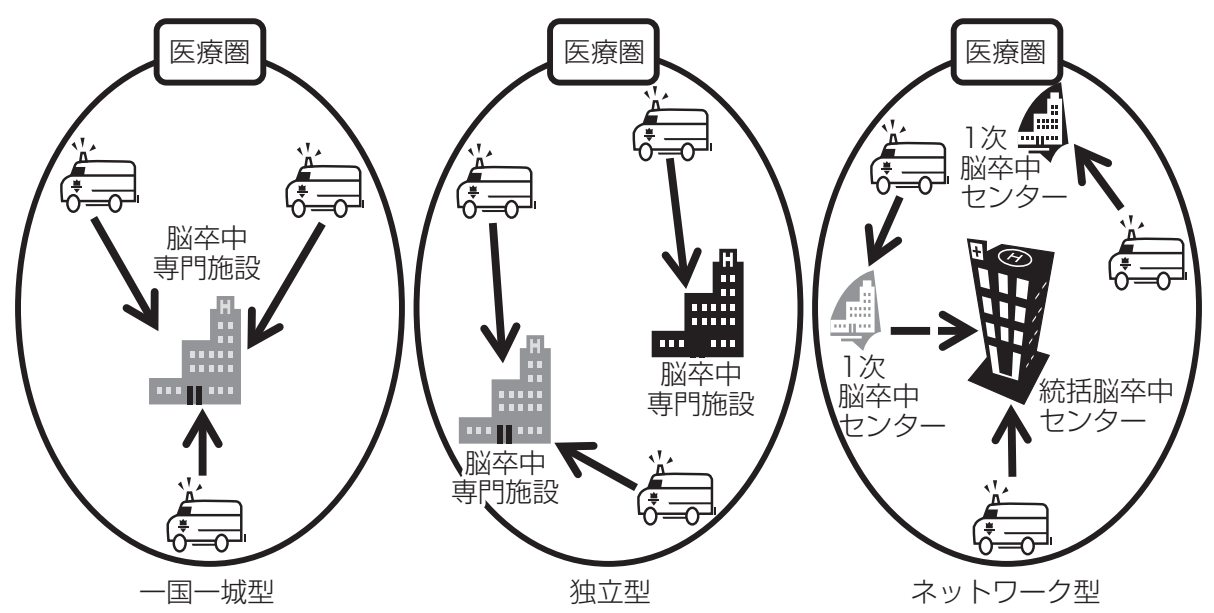

図 2. 医療圏の実態に準じた脳卒中急性期医療の地域連携モデル

【一国一城型】急性期脳卒中疑し傷病者は脳卒中專門施設（1 次脳卒中センターもしくは 統括脳卒中センター）に搬送する。【独立型】複数ある脳卒中専門施設へ搬送する.【ネッ トワーク型】急性期脳卒中疑し傷病者は複数ある機能特化した脳卒中專門施設へ搬送する. 1 次脳卒中センターで対応不可能な場合には, 遅滞なく統括脳卒中センターへ搬送する. (峰松一夫監修 新版脳梗塞rt-PA静注療法実践ガイド＼cjkstart改編）

実践することである. 脳卒中対策基本法等の法 整備を進め, 行政を中心とした脳卒中啓発活動 に関する枠組み作りを進めることが重要である.

\section{PSLS}

PSLSは脳卒中疑い傷病者に対する救急隊の病 院前救護活動を体系化, 標準化したものである. PSLSの目的は, 治療対象となりうる脳卒中疑い 傷病者を一人でも多く,できるだけ早く脳卒中 専門施設へ搬送することである．救急隊は，傷 病者収容現場で一般的な傷病者に対する初期対 応手順（acute medical life support）を，脳卒中 疑い傷病者に対しては初期対応と同時にPSLS を実践する．PSLSを円滑に実施するためには， 救急隊によるワイド・トリアージを許容するこ と, 脳卒中専門病院は救急隊に対して最終診断 名をfeed backすることが重要である.

PSLSは都道府県もしくは 2 次医療圈を 1 単位 としたmedical control協議会 (MC協議会) で制
定される.MC協議会では, 消防本部, 医師会, 地域医療機関, 行政, 保健所等が参加し, 地域 の救急医療体制のあり方（救急隊の処置基準, 搬送ルール作り，事後検証等）を議論する。さ らに各医療圈における脳卒中専門施設の数, 規 模, 診療実態, 消防本部の活動状況, 交通網の 整備などを勘案した地域脳卒中診療体制（傷病 搬送現場・病院間，病院・病院間搬送体制）を 構築する (図 2). 現状ではPSLSに対するMC 協議会の取り組みは地域間でばらつきがあり， 全国レベルでの実態調查と体制整備には至って いない.

PSLSを構成する要素は 1 . 救急搬送システム の標準化に対する教育プログラム, 2. 病院前脳 卒中スケールを用いた適切な評価, 3. 脳卒中専 門施設への優先的搬送 (stroke bypass), 4. 施 設到着前の傷病者情報提供からなる。

1) 救急搬送システム標準化に対する教育プロ グラム

救急搬送を円滑に進めるには，搬送要請した 


\section{トピックス}

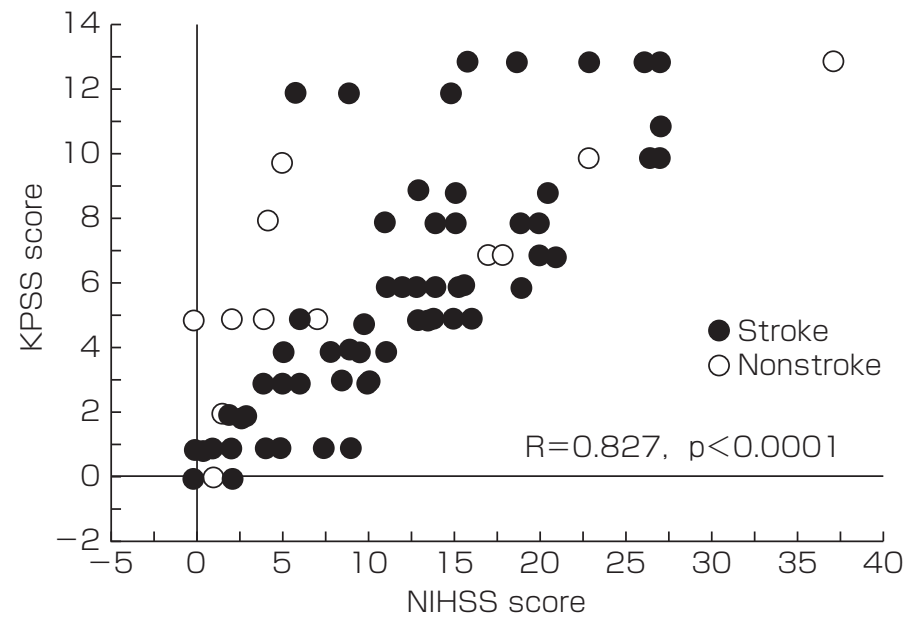

図 3

National Institutes of Health Stroke Scale (NIHSS) と (Kurashiki Prehospital Stroke Scale (KPSS) は良好な相関 を示す.

市民，消防本部，救急隊間で標準化された情報 （例：最終無事確認時刻, 発見時刻, 必要最小限 の神経症状等）を共有することが重要である. 消防本部は救急要請を行った市民から, 発症状 況等の情報を入手し，さらに消防本部はその情 報から「脳卒中疑い」と迅速に判断し救急隊に 収容・搬送を指示する。搬送手順に関する教育 プログラムの標準化により, t-PA静注療法実施 率は上昇する。

\section{2）病院前脳卒中スケール}

病院前脳卒中スケールは, 救急隊が脳卒中疑 い傷病者に対して搬送現場で実施する評価ツー ルである．救急隊が傷病者を脳卒中か否か判別 する「病院前脳卒中選別スケール」, 救急隊が脳 卒中疑い傷病者の神経症状の重症度を評価する 「病院前脳卒中重症度評価スケール」が運用され ている. 病院前脳卒中選別スケールは, Cincinnati Prehospital Stroke Scale (CPSS), Los Angeles Prehospital Stroke Screen（LAPSS）であ る. 病院前脳卒中重症度評価スケールは, 倉敷 病院前脳卒中スケール（Kurashiki Prehospital
Stroke Scale ; KPSS $)^{4)}$, shortened version of the National Institutes of Health Stroke Scale (sNIHSS), Los Angeles Motor Scale (LAMS) で ある。病院前脳卒中スケールは，1）運用現場で の簡便性と正確性，2) 統計処理に耐えうる信頼 性が要求される.

\section{(1) CPSS}

1999 年にKothariらにより開発されたCPSS は, (1)顔面麻疩，(2)上肢麻疩，(3)言語障害に関 する評価項目をNIHSSから抽出した「病院前脳 卒中選別スケール」である。CPSSは，前方循環 系の脳卒中への感度が高い。脳卒中疑い傷病者 と評価できる精度は，3 項目のうちいずれか 1 つ陽性で，感度 $66 \%$, 特異度 $87 \%$ である。

(2) LAPSS

CPSSと同時期にKidwellらが開発したLAPSS は, 神経症状（顔面麻痺, 手掌の筋力低下, 上 肢の筋力低下), 年齢, てんかんの既往, 発症時 間，発症前の生活状況，血糖を評価する．全項 目で「はい」と評価した場合のLAPSSの精度は, 感度 $91 \%$, 特異度 $97 \%$ である。 


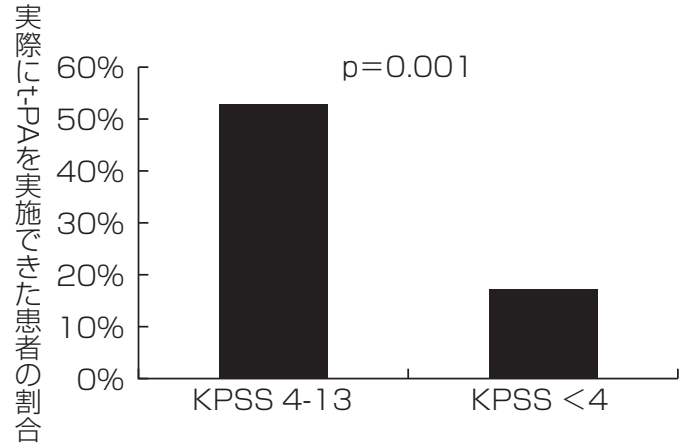

図 4

KPSS が 4 を超えた超急性期脳梗塞例の $52 \% に$ t-PA静注療法が実施可能である.

\section{(3) KPSS}

KPSSはPSLSガイドライン (監修：日本臨床救 急医学会）で推奨されている病院前脳卒中重症 度評価スケールである ${ }^{5)}$. 意識水準, 意識障害 (質問), 左右上肢および下肢の運動機能, 言語 の全 7 項目を評価し, 神経症候を認めない場合 は 0 点, 最重症は 13 点である. 救急隊が評価し たKPSSスコアと脳卒中診療専門医師が評価した NIHSSスコアは良好な相関を示す $(\mathrm{R}=0.827, \mathrm{p}$ $<0.0001$, 図 3). t-PA静注療法は, KPSS $\geqq 4$ であった 58 例中 30 例 $(52 \%)$ に実施可能であっ だ（図 4). KPSSと脳梗塞発症 3 力月後の転帰は 関連性が高く, KPSS $<3$ は転帰良好に関連する 独立した因子であった(オッズ比 $3.0 ； 95 \%$ 信頼 区間 $1.2 \sim 7.3 ; \mathrm{p}=0.015)$.

\section{3) stroke bypass}

stroke bypassとは, 救急隊が急性期脳卒中疑 い傷病者を直近施設ではなく，脳卒中専門施設 へできる限り早く搬送するシステムである。 stroke bypassはONTの短縮 (病院前脳卒中救護 体制の改善)，DNTの短縮 (院内脳卒中診療体制 の改善）に寄与する. stroke bypassの整備には 医療圈における医療機関の配置, 人口密度の偏 り，道路網整備など様々な因子を勘案する必要 があり, 前述のとおり MC協議会の主導によるシ
ステム作りが重要である.

\section{4）施設到着前の傷病者情報提供}

脳卒中専門施設は救急隊から急性期脳卒中診 療に必要な傷病者情報を入手することにより, ODT (onset-to-door time), 来院から画像検査開 始までの時間, DNTいずれもが短縮し, t-PA 静注療法実施率は上昇する.「脳卒中専門施設到 着前に行うべき事はできる限り済ませ，到着後 に行うべき事は最小限とする」ことがDNT短縮 に重要である ${ }^{2}$. 救急隊と脳卒中専門施設間での テレビ電話等を用いた医療情報共有システム (prehospital teleconsultation) は実用化にむけて試用 されている.

\section{3. 遠隔診療支援システム}

t-PA静注療法が認可されて 2 年経過した時点 で全国の入院可能な医療施設にアンケート調査 を実施したところ,「急性期脳卒中の診療は可能 だが，超急性期脳梗塞に対するt-PA静注療法は 実施できない」施設が多数存在することが明ら かになった ${ }^{7)}$. その主たる原因は脳卒中専門診療 医師の不足であった，脳卒中急性期医療の地域 間格差を解消するには，1)ヘリコプターによる 患者搬送, 2) mobile stroke unit, 3） telemedicine などの遠隔診療支援システムが試用されている.

1）ヘリコプターを使用した患者搬送システム

ヘリコプターを用いた傷病者搬送システムは 道路網が十分に整備されていない島嶼・山間地 域で実施されている．脳卒中疑い傷病者に対す るへリコプター搬送により, ODTは短縮しt-PA 静注療法実施率は上昇する. 医師同乗型へリコ プター搬送（ドクター・ヘリ）を実施している 川崎医科大学附属病院では, ドクター・ヘリに よる年間搬送件数は 450 件, うち約 $1 / 4$ は急性 期脳卒中疑い傷病者である. t-PA静注療法を実 施した超急性期脳梗塞例の約 10\% はドクター・ ヘリによる搬送であった. 北米では傷病現場/脳 


\section{トピックス}

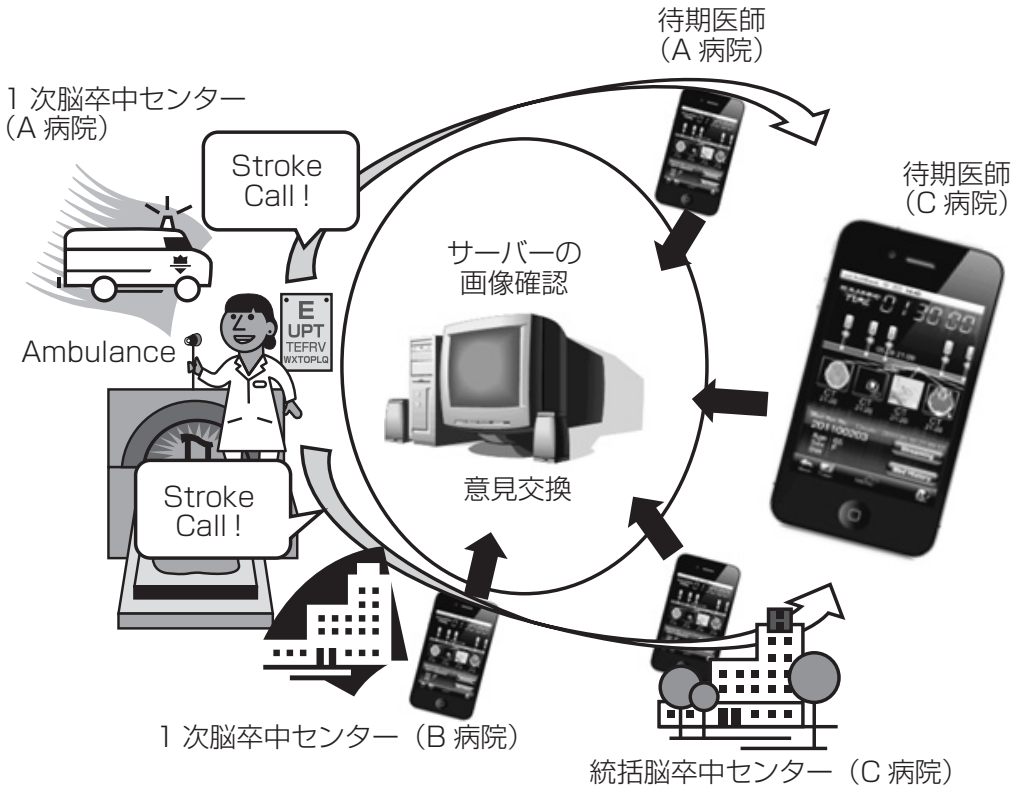

図 5. Synapse ERm ${ }^{\circledR}$ を用いたネットワーク型地域脳卒中診療体制

1 次脳卒中センターにt-PA静注療法対応となる超急性期脳梗塞例が搬送された場合には, 1 次脳卒中センター（A病院）が「stroke call」を発信する. 同時にサーバー上には, 対 象患者の神経画像が保管される. stroke callは携帯端末を所持している地域すべての脳 卒中診療担当医師に通知される. virtual private networkで保護されたプロトコールに 従い各医師はサーバ一内の神経画像を閲覧し，ネットワーク上で意見交換が可能である. A病院での対応に限界がある（例：t-PA静注療法は可能だが, その後に実施が予想される 血管内治療は実施不可能）場合には, t-PA静注療法を実施しながら統括脳卒中センター (C 病院）に搬送する (drip, ship, and retrieve).

卒中センター間の搬送だけではなく, 1 次脳卒中 センターに搬送後t-PA静注療法を実施しながら ヘリコプターを用いて統括脳卒中センターに搬 送し，血管内治療等より高度な医療を提供する 「drip, ship, and retrieve」を実践している.

\section{2) mobile stroke unit}

脳卒中疑い傷病者を対応可能な脳卒中専門施 設に搬送するシステムは各医療圈の実情に応じ て様々である。高速道路網が発達している欧州 では「mobile stroke unitを用いた病院前救護」を 展開し成果をあげている ${ }^{8)}$. mobile stroke unit （CT (computed tomography）およびt-PA静注 療法キット等を搭載した救急搬送車を使用した 病院前脳卒中診療）では救急指令部が脳卒中疑
い傷病者の情報を入手した時点で, 脳卒中診療 専門医師が傷病現場に急行する。脳卒中診療専 門医師は傷病現場でCTを含む初期診療を実施し, 超急性期脳梗塞と診断した時点で直ちにt-PA 静注療法を開始する. mobile stroke unitの運用 によりONTは短縮する.

3) telemedicine

テレビ電話, ビデオ会議, 画像転送等を駆使 した医療情報共有システムは, 様々な医療現場 で実施されている，急性期脳卒中診療では，ビ デオ会議と画像転送を組み合わせたtelestroke が運用されている，1)急性期脳卒中患者を収容 できない地域病院と脳卒中専門施設間telestroke, 2) 脳卒中専門施設内telestroke, さらに3) 脳卒 
中専門施設間 (1 次脳卒中センター・統括脳卒中 センター間) telestrokeなどが試されている。米 国脳卒中協会で監修されたガイドラインでは, ビデオ会議システムの用件が厳密であり, 少な くとも毎秒 20 frame以上のビデオカメラの使用, 13 インチ以上のモニタ使用を推奨している ${ }^{9)}$. 地 域病院においてtelestrokeを用いてt-PA静注療法 を円滑に実施するためには，まず地域病院の担 当医師が急性期脳卒中診療の手順を理解し, NIHSSを用いて脳卒中専門施設の脳卒中診療専 門医師とともに患者の神経症候をリアルタイム に評価, さらに頭部CT/MRI(magnetic resonance imaging)などの神経画像検査を適切に評価し治 療することが推奨されている.

\section{(1) stroke mobile telemedicine (SMT)}

固定回線テレビ電話を用いたtelestrokeは, 機 器設置にかかる費用, テレビ電話/ビデオカメラ がある部署での運用に限定される等の問題点が ある。この問題点を解消するために, 脳卒中専 門施設・地域病院間にテレビ電話機能付き携帯 端末（SMT）を配備し，SMT実施の有無で急性 期脳梗塞例の転帰が改善するかを検証した ${ }^{10)}$. 全 国 9 地域（23 施設）において研究期間前半は既 存の診療体制（非SMT実施群）を, 後半はSMT を実施した (SMT実施群)。非SMT実施群は 66 例, SMT実施群は 68 例を登録した. 1 力月後の 転帰を追跡しえた脳梗塞例では, 非SMT実施群 40 例中t-PA療法は 1 例（3\%）に実施, SMT 実施群 34 例中 4 例 $(12 \%)$ に実施 $(\mathrm{p}=0.173)$ ， 転帰良好 (modified Rankin scale 0～2) は, 非SMT 実施群 19 例（48\%), SMT実施群 15 例（44\%） であった. SMT実施後t-PA療法実施率は $3 \%$ か ら $12 \%$ に上昇し, SMTは地域の脳卒中診療支援 に有用であることが示唆された．急性期脳卒中 患者受け入れ体制を本邦でくまなく構築するた めには，脳卒中診療専門医師の増員が自明であ る。しかしながら大幅な医師増員を短期間に実 現することは困難である．脳卒中診療専門医師
を全国に配備するまでの過渡期においては，地 域病院と脳卒中専門施設間にSMTを構築するこ とにより，脳卒中診療専門医師不足に起因する 診療体制の病院間・地域間格差が改善する可能 性がある。

\section{(2) Synapse $\mathrm{ERm}^{\circledR}$}

Smart Phoneもしくはタブレット型携帯端末を 使用した医療情報共有システムが注目を集めて いる ${ }^{11)}$. Synapse $\mathrm{ERm}^{\circledR}$ （旧i Stroke）は, 脳卒 中専門施設内もしくは脳卒中専門施設間 (1 次脳 卒中センター・統括脳卒中センター間）の診療 情報共有を目的に開発された（図 5)。携帯端末 を所持している医療者は, インターネット回線 に接続できる環境下でサーバー内の画像にアク セスし，施設内モニ夕と遜色ない解像度の神経 画像が確認可能である。サーバー・端末間の接 続はvirtual private networkで保護されているこ と, サーバー内の神経画像は 48 時間のみ保管さ れ，その後はアクセス不可能である点が特徵で ある．本システムの運用により，都市型医療圈 における脳卒中センター間のネットワーク構築 が容易になるであろう. Synapse ERm ${ }^{\circledR}$ は本邦お よび米国でも運用されており, prehospital teleconsultationを含めた多施設共同研究によるSynapse $\mathrm{ERm}^{\circledR}$ の有効性に関する検証が待たれる。

（3） telestrokeに関わる問題

画像所見転送システムによる神経画像の評価 は本邦において実地運用されている。一方でビ デオ会議システムの運用は限定的である. telestrokeの普及に向けた課題は, 1) 診療責任に 関する法整備，2)診療請求に関する規定，3）地 域医療機関の受け入れ体制（初期脳卒中診療が 可能な医療者の育成等）である.

おわりに

脳卒中急性期医療の地域連携と telemedicine について概説した. 継続的かつ効果的な脳卒中 
啓発活動, PSLSの運用と検証, 脳卒中疑い傷病 者を継続的に受け入れ最適な医療を提供する脳 卒中専門施設の整備が重要である. telemedicine 等の遠隔診療支援システムを活用しながら医療 資源を効率的に配分する。脳卒中急性期医療シ ステムのさらなる改善により，国民の厚生が向 上することを期待したい。

著者のCOI (conflicts of interest) 開示：本論文発表内容に 関連して特に申告なし

\section{文献}

1) Iguchi $Y$, et al: Stroke incidence and usage rate of thrombolysis in a Japanese urban city : the Kurashiki Stroke Registry. J Stroke Cerebrovasc Dis 22 : 349-357, 2013.

2) Fassbender K, et al : Streamlining of prehospital stroke management : the golden hour. Lancet Neurol 12 :585596,2013

3) Iguchi $Y$, et al : First impression at stroke onset plays an important role in early hospital arrival. Intern Med 45 : 447-451, 2006

4) Kimura K, et al: Kurashiki Prehospital Stroke Scale. Cerebrovasc Dis 25 : 189-191, 2008.
5）井上 剛, 木村和美 : 倉敷病院前脳卒中スケール, PSLS コースガイドブック (救急隊員による脳卒中の観察・処 置の標準化). 日本臨床救急医学会編. へるす出版, 東京, 2007, 19-22.

6) Iguchi Y, et al: Utility of the Kurashiki Prehospital Stroke Scale for hyperacute stroke. Cerebrovasc Dis 31 : 51-56, 2011.

7）井口保之, 他：急性期脳卒中患者受け入れ体制に関する 全国病院実態調査研究 (J.TEAMs study). 脳卒中 31 : 141-147, 2009

8) Walter $\mathrm{S}$, et al : Diagnosis and treatment of patients with stroke in a mobile stroke unit versus in hospital : a randomised controlled trial Lancet Neurol 11 : 397-404, 2012.

9) Schwamm LH, et al: A review of the evidence for the use of telemedicine within stroke systems of care : a scientific statement from the American Heart Association/ American Stroke Association. Stroke 40: 2616-2634, 2009.

10）井口保之, 他：テレビ電話機能付き携帯端末を用いた遠 隔診療支援システム (stroke mobile telemedicine: SMT) の臨床応用. 脳卒中 $33: 1-8,2011$.

11) Takao H, et al: A new support system using a mobile device (smartphone) for diagnostic image display and treatment of stroke. Stroke 43 : 236-239, 2012. 